\title{
World commerce, world politics, world English
}

In 1995, Ballantine Books published in New York a book by Benjamin R. Barber. Its title was Jihad vs. McWorld, a phrase that would not have made much (any?) sense in 1895, or been easily unpacked even in 1975. It is often in word capsules like these that we see how much a language can change in a century, so as to put Arabic jihad alongside Latin versus while attaching Gaelic Mc (courtesy US fast food) to world, the only bit of original AngloSaxon. Barber also provided the subtitle 'How globalism and tribalism are reshaping the world', and it is the use of globalism that particularly interests me here. 1995 was a key year for globalization as a label for the worldwide spread of Western and especially US notions and practices relating to trade and technology. On page 23 of his book, Barber says:

- 'Welcome to McWorld. There is no activity more intrinsically globalizing than trade, no ideology less interested in nations than capitalism, no challenge to frontiers more audacious than the market.'

Barber's work came out two years before David Crystal's English as a global language, on page vii of which he notes:

- It has all happened so quickly. In 1950, any notion of English as a true world language was but a dim, shadowy, theoretical possibility, surrounded by the political uncertainties of the Cold War, and lacking any clear definition or sense of direction. Fifty years on, and World English exists as a political and cultural reality. How could such a dramatic linguistic shift take place, in less than a lifetime?

For many people around the world this 'linguistic shift' is now simply one of the givens in life. As 'the international review of the English language', ET has for close on two decades served as a forum for comment on just this jihadic and McWorldian shift. This issue looks at 'world English', 'international English', and 'global English' as competing names for the language that thrives on such titles as Barber's. It also looks at the vastly significant cohabitation of Spanish and English in the USA, at the world's language academies, at 'different from' and 'different than', at codemixing journalism in India, at ESL in China, at 'Cyber War', at folk etymology, how we sound our consonants, and 'talk shows' in New York. World English indeed.

Tom McArthur

The editorial policy of English Today is to provide a focus or forum for all sorts of news and opinion from around the world. The points of view of individual writers are as a consequence their own, and do not reflect the opinion of the editorial board. In addition, wherever feasible, ET generally leaves unchanged the orthography (normally British or American) and the usage of individual contributors, although the editorial style of the journal itself is that of Cambridge University Press. (c) Cambridge University Press 2004. No contents may be reproduced by any means without the permission of Cambridge University Press.

English Today (ISSN 0266-0784) is a quarterly.

Publisher: Cambridge University Press, The Edinburgh Building, Cambridge CB2 2RU, United Kingdom. Telephone (01223) 312393 Email:

journals marketing@cup.cam.ac.uk Subscriptions: The 2004 subscription price (excluding VAT) for four issues for libraries and institutions, which includes print and electronic access, is f85.00 outside of North America; $\mathrm{f} 32.00$ for individuals; $\mathrm{f} 26$ for students and the retired. The electronic-only price available to institutional subscribers is $f 75.00$. Prices include delivery by air where appropriate. Apply to Jane Crossland at the above address.

Advertising Sales: write to the Advertising Promoter at the above address.

USA, CANADA AND MEXICO: Publisher: Cambridge University Press, 40 West 20th Street, New York, NY 10011-4211, USA.

Telephone (212) 9243900.

Subscriptions: The 2004 subscription price (excluding VAT) for four issues for libraries and institutions, which includes print and electronic access, is $\$ 134.00$ in USA, Canada and Mexico; $\$ 50.00$ for individuals; $\$ 38$ for students and the retired. The electronic-only price available to institutional subscribers is $\$ 113.00$. Apply to Marianne Headrick at the above address.

Advertising Sales: write to the Advertising Coordinator at the above address.

Periodicals postage paid at New York, NY and at additional mailing offices. POSTMASTER: send address changes in USA, Canada and Mexico to English Today, Cambridge University Press, 110 Midland Avenue, Port Chester, New York, NY 10573-4930, USA.

Japanese prices for institutions are available from Kinokuniya Company Ltd, P.O. Box 55, Chitose, Tokyo 156, Japan.

Contacting the Editor: Email Dr Tom McArthur at <Scotsway@aol.com> or write to him at 22-23 Ventress Farm Court, Cherry Hinton Road, Cambridge CB1 8HD, UK. Tel 01223245934.

Internet access This journal is included in the Cambridge Journals Online service which can be found at http://uk.cambridge.org/journals. For further information on other Press titles access http://uk.cambridge.org.

Designed and typeset by Peter Ducker. Printed in the United Kingdom at the University Press, Cambridge. 